\title{
PEDAGOGIKA PookXIII
}

\section{Nr2(27) SPOŁECZNA}

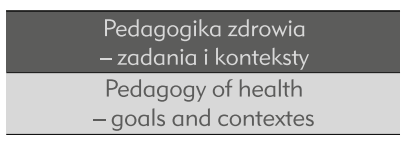

\section{Ewa Syrek}

\section{Teoretyczne podstawy współczesnej pedagogiki zdrowia jako subdyscypliny pedagogiki}

\section{The theoretical basis of contemporary health pedagogy as a pedagogical subdiscipline}

A B S T R A C T: The article presents the Social-Ecological model of health and elements of the classical concept of social pedagogy, indicating the theoretical basis of pedagogy in health promotion with its cognitive and scientific interest and emphasizes environmental health education in the context of its practical application. The article also indicates the social pedagogy as a meta-theory of contemporary pedagogy in health promotion.

KE Y W O R D S: Pedagogy in health promotion, social pedagogy, health education, The Social-Ecological Model, environment.

Streszczenie: Artykuł prezentuje społeczno-ekologiczny model zdrowia i elementy klasycznej koncepcji pedagogiki społecznej, wskazując podstawy teoretyczne pedagogiki zdrowia z zaznaczeniem jej przedmiotu zainteresowań poznawczo-naukowych oraz akcentuje środowiskową edukację zdrowotną w kontekście jej praktycznego zastosowania. Ukazuje pedagogikę społeczną jako metateorię współczesnej pedagogiki zdrowia.

SŁoWA KLUCZOWE: Pedagogika zdrowia, pedagogika społeczna, edukacja zdrowotna społeczno-ekologiczny model zdrowia, środowisko. 


\section{Wprowadzenie}

Problematyką szeroko rozumianego zdrowia i jego uwarunkowaniami interesują się od wielu dekad przedstawiciele nauk nie tylko medycznych ale i humanistyczno-społecznych. Zdrowie (health) nie jest pojęciem jednoznacznym, a podejścia do jego definiowania są różne. Najbardziej znaną i często cytowaną w literaturze przedmiotu jest definicja zdrowia sformułowana przez Światową Organizację Zdrowia (World Health Organization, WHO), według której zdrowie to stan dobrego samopoczucia fizycznego, psychicznego i społecznego, a nie tylko brak choroby lub niepełnosprawności. Definicja ta wskazuje na trzy wymiary (dimensions of health) zdrowia wzajemnie ze sobą powiązane: wymiar fizyczny (physical dimension) odnoszący się do somatyki i organizmu człowieka, wymiar psychiczny (psychological dimension), którego miarą jest zintegrowana osobowość, rozwój osobisty itp. oraz wymiar społeczny (social dimension) obejmujący wzajemne relacje międzyludzkie, pełnienie ról społecznych, uczestnictwo społeczne. Współczesne różne podejścia do definiowania zdrowia ukierunkowane są pozytywnie, np. zdrowie jako brak choroby, jako zdolność adaptacyjnego wieloaspektowego funkcjonowania człowieka w środowisku, jako potencjał fizyczny i psychiczny, jako równowaga w funkcjonowaniu fizycznym, psychicznym i społecznym człowieka w środowisku, jako dobra jakość życia, samorealizacja, szczęście (Woynarowska 2017, s. 16-18; Domaradzki 2013, s. 408-415). Należy zwrócić także uwagę na wymiar duchowy zdrowia (spiritual dimension), który ujmowany jest w psychologii zdrowia ,jako właściwości (atrybuty) człowieka, bez przyjmowania założeń dotyczących istnienia czynników nadprzyrodzonych stanowiących jej źródło" (Heszen, Sęk 2007, s. 72-73; zob. także: Mielec 2009). Wymienione kategorie / wymiary zdrowia stanowią spójną komplementarną całość i oznaczają równorzędność znaczenia dla zdrowia czynników fizycznych, psychicznych i społecznych. Liczne i zróżnicowane uwarunkowania zdrowia / choroby stanowią wieloczynnikowy problem związany $\mathrm{z}$ analizą ich znaczenia dla zdrowia / choroby człowieka. L. Marc Lalonde w 1973 r. na Światowym Zgromadzeniu Zdrowia w Kanadzie zaproponował Pola zdrowia (Health field cocept), wyróżniając cztery grupy czynników, które determinują zdrowie człowieka i populacji: styl życia i zachowania zdrowotne determinują zdrowie w największym stopniu (50\%-60\%), środowisko fizyczne, psychospołeczne, kulturowe, czynniki, genetyczne i służba zdrowia w zdecydowanie mniejszym stopniu. W literaturze przedmiotu istnieje wiele modeli uwarunkowań zdrowia, np. Mandala zdrowia - model ekosystemu człowieka, Tęcza 
czynników (polityki) zdrowia (policy rainbow) opracowany w Szwecji przez Goran Dahlgrena i Margaret Whitehead (poźniej modyfikowany), w którym wyodrębnia się następujące grupy czynników: biologiczne (wiek, płeć, czynniki genetyczne), styl życia, sieci wsparcia społecznego oraz czynniki społeczno-ekonomiczne, kulturowe i środowiskowe (Woynarowska 2007, s. 43-47). Zwrócenie uwagi nie tylko na indywidualne, ale i kulturowe, społeczno-ekonomiczne i środowiskowe uwarunkowania zdrowia człowieka i społeczeństwa spowodowało, że badacze różnych dyscyplin naukowych zajęli się poznawaniem wpływu tych komponentów na zdrowie / chorobę człowieka i populacji. W obrębie pedagogiki, socjologii i psychologii wyodrębniły się subdyscypliny (pedagogika zdrowia, socjologia zdrowia i choroby, psychologia zdrowia), które wskazują na interdyscyplinarne zainteresowanie zdrowiem / chorobą z perspektywy własnego przedmiotu zainteresowań poznawczo-badawczych. Istotne wydaje się podkreślić, iż przedmiotem badań pedagogiki zdrowia, socjologii zdrowia i choroby oraz psychologii zdrowia są zdrowie i choroba analizowane z perspektywy obszaru zainteresowań badawczych dyscyplin podstawowych, tj. pedagogiki, socjologii i psychologii, ich obszary zainteresowań poznawczo-badawczych nieustannie się poszerzają wraz ze współcześnie dokonującymi się zmianami społeczno-kulturowymi (np. zmiany stylu życia) czy też ekonomicznymi. W przyjętych przez wymienione subdyscypliny analizach podstawą jest społeczno-ekologiczny model zdrowia i holistyczno-podmiotowe taktowanie człowieka ukierunkowane na zdrowie. Ponadto wyniki badań i prowadzonych analiz mają wymiar praktyczny i stanowią istotny wkład w rozwój promocji zdrowia. Warto zauważyć, iż w ostatnich dekadach zwiększa się liczba publikacji uwzględniających problematykę zdrowia i choroby z perspektywy poszczególnych subdyscyplin, a powoływanie licznych instytucji (np. towarzystw, czasopism, zakładów, katedr) oraz włączenie określonych specjalności (także i przedmiotów) w proces kształcenia ogólnego i akademickiego są ważnymi krokami w rozwoju tych subdyscyplin (zob. Syrek 2017, s. 57). Celem artykułu jest prezentacja współczesnego społeczno-ekologicznego modelu / koncepcji zdrowia i wskazanie wybranych zagadnień związanych z klasyczną koncepcją pedagogiki społecznej jako teoretycznych podstaw pedagogiki zdrowia, określenie przedmiotu zainteresowań naukowo-badawczych pedagogiki zdrowia $\mathrm{z}$ uwzględnieniem środowiskowej edukacji zdrowotnej. Ponadto zwrócenie uwagi na istotne, nie zawsze dostrzegane, relacje między pedagogiką zdrowia a pedagogiką społeczną. W tekście nie uwzględniono społecznych kontekstów choroby i społecznej roli chorego (zob. Parsons 1993), ponieważ jest to zagadnienie o złożonych kontekstach i wymaga odrębnego potraktowania. 


\section{Społeczno-ekologiczny (środowiskowy) model zdrowia}

Zdrowie jest wartością i zasobem dla jednostki i społeczeństwa. System wartości preferowany w danej kulturze ma wpływ na indywidualne zachowania, dokonywane wybory (także w zakresie zdrowia), sposób zaspokajania potrzeb, przypisywanie znaczenia różnym elementom środowiska. Indywidualne wartościowanie zdrowia ma wymiar subiektywny ale, co ważne, jest zdeterminowany kulturą zbiorowości, w której aktualizował się proces socjalizacji. Zróżnicowanie poglądów na zdrowie, przyjęcie kryteriów zdrowia, uznanie wartości przypisywane zdrowiu czy też zagrożeń zdrowia, preferowanie określonego stylu życia, stosunek do ludzi chorych / niepełnosprawnych są odmienne $\mathrm{w}$ różnych kulturach $\mathrm{w}$ sensie globalnym, ale i lokalnym ( $\mathrm{w}$ danym społeczeństwie). Ponadto $\mathrm{w}$ każdym społeczeństwie występują zróżnicowania kulturowo-środowiskowe $\mathrm{w}$ przedmiotowych kwestiach. Wartości uzasadniają normy moralne i są podstawą kontroli społecznej (oceny), zmieniają się w historycznej przestrzeni, ich rozumienie zależy od klasy społecznej (Tobiasz-Adamczyk 2000, s. 73-75, 69). Zdrowie jednostki jest podstawą realizacji jej celów życiowych, samorealizacji, sukcesu życiowego, warunkuje jakość życia (zob. np. Czapiński 2017). W ostatnich dekadach nastąpił rozwój refleksji teoretycznej nad problemami zdrowia, edukacji zdrowotnej i ochrony zdrowia jako określonej sfery zachowania społecznego. Zdrowie bowiem, jako zasób jednostki i społeczeństwa, stanowi ważny element kapitału ludzkiego i kapitału społecznego (social capital). Pierre Bourdieu w 1980 roku zdefiniował pojęcie kapitału społecznego jako „zbioru aktualnych lub potencjalnych zasobów, które wiążą się z posiadaniem trwałej sieci mniej lub bardziej zinstytucjonalizowanych relacji wzajemnej znajomości lub rozpoznawania się" (cyt. za Sztompka 2016, s. 287). Piotr Sztompka analizuje kapitał ludzki, ukazując jego wielowymiarowość, np. kapitał edukacyjny, kulturowy, moralny oraz zwraca uwagę na kapitał zdrowotny związany z dobrostanem fizycznym / biologicznym i psychicznym, wskazując z jednej strony korzyści dla jednostki, a z drugiej strony na korzyści społeczne związane $\mathrm{z}$ redukcją kosztów związanych ze zwolnieniami z pracy oraz kosztów leczenia czy rehabilitacji. Pragnę nadmienić, iż tych korzyści dla społeczeństwa jest znacznie więcej. Analizując zagadnienia społecznego kontekstu zdrowia konieczne jest wskazanie także na kapitał kulturowy związany znacząco $\mathrm{z}$ procesem socjalizacji i wychowania określony przez P. Bourdieu jako „habitus” (Sztompka 2016, s. 283). W nawiązaniu do tej koncepcji można określić socjalizację zdrowotną jako proces akulturacji zdrowotnej polegającej na przygotowaniu wychowanka do dokonywania wybo- 
rów zdrowotnych / zachowań zdrowotnych zgodnych z kulturowo-środowiskowymi, akceptowanymi społecznie wzorami i normami społecznymi. W praktyce życia społecznego te dwie odmiany kapitału - indywidualny i społeczny - są wzajemnie powiązane, co podkreśla się m.in. w dokumentach Światowej Organizacji Zdrowia (zob. np. Zdrowie 21; Zdrowie 2020). Podstawą analiz dotyczących zdrowia / choroby człowieka jest jego holistyczne postrzeganie / rozumienie, podobnie jak to zakłada społeczno-ekologiczny model zdrowia, który wskazuje, że człowiek pozostaje we wzajemnej, skomplikowanej relacji z szeroko rozumianym środowiskiem. Model ten nawiązuje do wcześniej wspomnianej Mandali Zdrowia - ekosystemu człowieka, opracowanej w Departamencie Zdrowia Publicznego Miasta Toronto w Kanadzie. Potrzeby człowieka i wymagania ze strony zmieniającego się środowiska wzajemnie na siebie oddziałują, podobnie jak (przykładowo) komplementarne względem siebie są potrzeby człowieka. Wszystkie wymiary zdrowia (fizyczne, psychiczne, społeczne, duchowe), jak i wszystkie elementy społeczno-ekologicznego modelu zdrowia są wzajemnie ze sobą powiązane funkcjonalnie, co wskazuje, że na zdrowie człowieka wpływa wiele czynników, wskazuje także na ważny problem nierówności w zdrowiu. We wspomnianym modelu człowiek zajmuje centralne miejsce, a otaczają go biosfera i kultura jako sfery najdalej oddalone od centralnej postaci jaką jest człowiek. Najbliżej jednostki znajduje się krąg rodzinny, który przenika pola uwarunkowań zdrowia, takie jak: zachowania zdrowotne, środowisko psychospołeczne i ekonomiczne warunkujące styl życia. Biologia człowieka i środowisko fizyczne stanowią środowisko stworzone przez człowieka, a elementami łączącymi są praca i system opieki medycznej. W modelu tym człowiek pojmowany jest jako całościowy system (biologiczny, umysłowy, duchowy). Na zdrowie człowieka oddziałuje wiele czynników, ale jest on indywidualnym podmiotem, który nadaje zdrowiu określoną wartość (Heszen, Sęk 2007, s. 64-66; Woynarowska 2007, s. 28-29). Nie można zatem analizować zagadnień zdrowia, choroby, terapii, promocji zdrowia bez uwzględnienia środowiska życia człowieka i faz jego życia, bez jego relacji ze zmieniającymi się warunkami życia. Współcześnie czynniki społeczno-ekonomiczne uważa się za najważniejsze determinanty zdrowia ludzi - jednostek, grup i społeczeństw. Społeczne uwarunkowania (social determinansts in health) zdrowia są zmienne i tworzą warunki życia jednostek i społeczności, generując nierówności w zdrowiu. Występują one w sytuacji, gdy grupy społeczne, które zajmują gorszą pozycję społeczną charakteryzują się systematycznie gorszym stanem zdrowia i są narażone na większe ryzyko utraty zdrowia niż grupy, które są bardziej uprzywilejowane, i co ważne, dotyczy to różnic, które są możliwe do uniknięcia i niesprawiedliwe (Mazur 2010, s. 20; zob. także 
np. Ostrowska 2010; Chrabąszcz i in. 2015; Wojtyniak i in. 2015; Cianciara 2015; Hosseinpoor i in. 2018). Należy w tym miejscu zwrócić uwagę na gradient społeczny, który „oznacza, że poziom zdrowia systematycznie poprawia się w miarę poprawy sytuacji społeczno-ekonomicznej ludności lub społeczności. Dlatego nierówności w zdrowiu niekorzystnie wpływają na wszystkich. Jest to zjawisko ogólnoświatowe, które dotyczy wszystkich krajów bez względu na poziom dochodów" (Zdrowie 2020, s. 2). Ważną kwestią, aczkolwiek wymagającą odrębnego potraktowania, jest poszukiwanie podejścia do wyjaśnienia czy też działań niwelujących społeczne przyczyny nierówności w zdrowiu, źródła których upatruje się m.in. w materialnym poziomie życia, uwarunkowaniach kulturowych związanych $\mathrm{np} . \mathrm{z}$ wartościami, stylem życia oraz systemem polityczno-gospodarczym (Woynarowska 2017, s. 81; zob. także np. Korzeniowska, Puchalski 2015). Opisany społeczno-ekologiczny model zdrowia powstał w opozycji do obowiązującego w XX wieku modelu biomedycznego, w którym dominującą koncepcją była orientacja patogeniczna. Model ten zakładał, że zdrowie jest zależne od wyposażenia genetycznego i struktury organizmu człowieka (Heszen, Sęk 2007, s. 317-318). Zwrócenie uwagi na kulturowe, społeczne i środowiskowe determinanty zdrowia i choroby oraz na wzajemne relacje człowieka ze środowiskiem stanowiły istotny przełom w podejściu do zdrowia człowieka, jego uwarunkowań i związaną ze zdrowiem jakością życia jednostek i społeczności.

\section{Pedagogika zdrowia - przedmiot badań i działania edukacyjne w środowisku}

W okresie Oświecenia pojawił się w Polsce nurt myśli o zdrowiu. Z biegiem czasu ukształtowała się koncepcja wychowania zdrowotnego dzięki specyficznemu połączeniu pedagogiki i medycyny. Jej autorami byli wówczas m.in. pedagog Grzegorz Piramowicz (1735-1801) i lekarz, biolog, chemik Jędrzej Śniadecki. Jego znakomita praca O fizycznym wychowaniu dzieci (1895) łączyła wiedzę medyczną z potrzebami wychowania. Szczególnym przejawem zainteresowania zdrowiem $\mathrm{w}$ oświeceniu było m.in. popularyzowanie wiedzy w różnego rodzaju wydawnictwach (np. Jean de La Lafontaine Dzienniki zdrowia dla wszystkich stanów - wydany w latach 1801-1802) oraz inne formy upowszechniania organizowane przez Warszawskie Towarzystwo Przyjaciół Nauk. Nadanie wychowawczego charakteru ruchowi higienicznemu w latach 80 . XIX wieku było w Polsce łącznikiem między środowiskiem lekarzy i pedagogów. Do czołowych przedstawicieli należeli wówczas lekarze: E. Madeyski, J. Tchorznicki, A. Winogrodzki, E. Piasecki, P. Gontkowski oraz pedagodzy: 
J.W. Dawid, M. Baranowski, A. Szycówna, S. Karpowicz i wielu innych. Autorzy ci propagowali wychowanie zdrowotne $\mathrm{w}$ elementarzach zdrowia, podręcznikach, pomocach dydaktycznych, muzeach. Działały liczne stowarzyszenia (np. Towarzystwo Higieny Praktycznej im. B. Prusa), ukazywało się wiele pism i periodyków dotyczących higieny, np. „Przyjaciel Zdrowia”, „Lekarz”, „Przegląd Higieniczny” i inne (Demel 1980, s. 28-37 i 74-80; zob. także Demel 1965; Zawadzka 2017). Można przytoczyć wiele przykładów zainteresowania zdrowiem w kontekście historycznym. Przedstawiam je jedynie sygnalnie, aby zwrócić uwagę czytelnika, że zainteresowanie problematyką zdrowia człowieka było obecne w przestrzeni historycznej od zarania dziejów i przejawiało się w różnych formach. W okresie międzywojennym i po roku 1945 podjęto pierwsze próby włączenia kwestii wychowawczo-zdrowotnej do pedagogiki społecznej („wychowanie dla spraw zdrowia”). Najbardziej twórcze inspiracje dla rozwoju pedagogiki zdrowia zawdzięczamy prekursorce pedagogiki społecznej w Polsce - Helenie Radlińskiej (1879-1954), która prowadziła badania środowiskowe dotyczące niepowodzeń szkolnych, które uwzględniały także sprawy zdrowia. Jej doświadczenia lekarskie i pielęgniarskie znalazły odzwierciedlenie $\mathrm{w}$ późniejszych pracach z zakresu pedagogiki empirycznej i teorii pracy socjalnej (Demel i in. 1976, s. 253-261). Podkreślała, że pedagogika społeczna musi sięgać do nauk biologicznych i medycznych, ponieważ korzysta ona $\mathrm{z}$ „badań nad zahamowaniami i skrzywieniami rozwoju indywidualnego, wprowadza dane o ich społecznych przyczynach, o możliwościach i sposobach zapobiegania i wyrównywania” (Radlińska 1961, s. 364). „Wychowanie dla spraw zdrowia" w klasycznej koncepcji pedagogiki społecznej Heleny Radlińskiej polegało na pomocy ludziom w zdobywaniu wiedzy o zdrowiu, kształtowaniu nawyków, umiejętności i sprawności służących utrwalaniu i doskonaleniu zdrowia, na pomocy w rozwijaniu pozytywnego zainteresowania zdrowiem, kształtowaniu postaw umożliwiających skuteczną profilaktykę, ratownictwo, leczenie, rehabilitację oraz stosowanie zasad higieny w życiu jednostek i zbiorowości. Analizując dokonania twórcze Heleny Radlińskiej w zakresie tworzenia klasycznej koncepcji pedagogiki społecznej wyraźnie dostrzega się, że współczesna pedagogika zdrowia znajduje oparcie w tej koncepcji w sensie poznawczo-teoretycznym, praktyki edukacyjnej oraz pracy socjalnej. Pojęcie środowiska stanowi podstawowe pojęcie w pedagogice, a zwłaszcza w pedagogice społecznej, rozumiane jest jako element struktury przyrodniczej, społecznej i kulturowej. Płaszczyzny te się wzajemnie przenikają i są ze sobą powiązane, niezależnie czy analizowane są problemy pedagogiczne, czy zdrowotne. $\mathrm{W}$ literaturze przedmiotu $\mathrm{z}$ zakresu promocji zdrowia, ale także i w pedagogice, coraz częściej pojawia się pojęcie środowisko życia, zwracając 
uwagę na konfigurację jego elementów (Marynowicz-Hetka 2006, s. 54-65). Środowisko życia człowieka to wszystkie komponenty wzajemnie powiązanych elementów przedstawionych w społeczno-ekologicznym modelu zdrowia nazywanym także modelem społeczno-funkcjonalnym.

Rozwój nauk społecznych i humanistycznych oraz zmieniająca się dynamicznie rzeczywistość społeczna stają się inspirującym obszarem badań naukowych oraz dyskusji / kontrowersji nie tylko wokół tożsamości pedagogiki jako nauki, ale również definiowania obszaru zainteresowań, przedmiotu badań i metodologii poszczególnych, rozwijających się subdyscyplin pedagogiki, w tym pedagogiki zdrowia. Koncepcje opisujące współczesną pedagogikę zdrowia jako subdyscyplinę pedagogiki są znacząco różne (zob. np. Mazurkiewicz 1983; Krawański 2003; Gaweł 2017; Syrek 2008). Jak podkreśla Bogusław Śliwerski (2015, s. 33): „W pedagogice XXI wieku pedagodzy doskonale zdają sobie sprawę $\mathrm{z}$ tego, że właśnie $\mathrm{w}$ pedagogice jako nauce o wychowaniu podejście interdyscyplinarne jest konieczne, gdyż rozwiązywanie problemów wychowawczych wymaga wykorzystania wiedzy z różnych nauk, by prowadząc analizę tego złożonego i wielowymiarowego zjawiska czy procesu, badać go holistycznie". Nawiązując do powyższej tezy warto zwrócić uwagę, iż Helena Radlińska zdefiniowała pedagogikę społeczną ,jako naukę praktyczną, rozwijającą się na skrzyżowaniu nauk o człowieku, biologicznych i społecznych z etyką i kulturoznawstwem (teorią i historią kultury) dzięki własnemu punktowi widzenia. Można je najkrócej określić jako zainteresowanie wzajemnym stosunkiem jednostki i środowiska, wpływem warunków bytu i kręgu kultury na człowieka w różnych fazach jego życia, wpływem ludzi na zapewnienie bytu wartościom przez ich przyjęcie i krzewienie oraz przetwarzanie środowisk siłami człowieka w imię ideału” (Radlińska 1961, s. 361). Klasyczna koncepcja pedagogiki społecznej Heleny Radlińskiej, a także jej kontynuatorów, Aleksandra Kamińskiego, Ryszarda Wroczyńskiego, i współczesnych badaczy respektowała i respektuje podstawowe idee: edukacji społecznej jako jednego z elementów życia społeczno-kulturowego, ideę podmiotowości, ideę sprawiedliwości społecznej wyrażającej się w równym dostępie do warunków, a których rozwija się człowiek, ideę pomocniczości, która jest realizowana poprzez działania społeczeństwa na rzecz jednostek, grup, środowisk potrzebujących pomocy (Przecławska 1996, s. 11). Pojęcie środowiska należy do podstawowych pojęć pedagogiki społecznej, i jak już wspomniano jest analizowane wieloaspektowo (zob. np. Marynowicz-Hetka 2006, s. 54-76; Winiarski 2017; Modrzewski 2018). Przyjętym przesłaniem w podjętych analizach jest twierdzenie Tadeusza Kotarbińskiego (1961, s. 450): „Im bardziej doskonali się dana dyscyplina praktyczna, tym relatywnie więcej pracy zajmuje $\mathrm{w}$ niej docie- 
kanie prawd $\mathrm{z}$ innych dziedzin, które to prawdy są potrzebne do zużytkowania ich dla głównych celów tej dyscypliny". Określając pedagogikę społeczną jako metateorię pedagogiki zdrowia przyjmuję, że przedmiot poznania, analizowania, badań naukowych i działań $\mathrm{w}$ pedagogice zdrowia wynika $\mathrm{z}$ podstaw teoretycznych pedagogiki społecznej i jej funkcji: „dyscyplina ta bowiem zajmuje się teorią środowiskowych uwarunkowań edukacji i rozwoju człowieka oraz teorią i praktyką kształtowania środowiska. Występującą często w tym kontekście pracę socjalną oraz pracę kulturalną, traktujemy jako formy przekształcania środowiska" (Przecławska 1996, s. 9). Wyniki poznania naukowego podejmowanego przez pedagogikę zdrowia - w obszarze szeroko rozumianej problematyki zdrowia - wzbogacają pedagogikę społeczną o wiedzę z zakresu kulturowych, społeczno-środowiskowych zróżnicowanych i wieloaspektowych uwarunkowań zdrowia / choroby, celem projektowania zmian $\mathrm{w}$ środowisku życia człowieka sprzyjających zdrowiu i poprawie jakości życia. Ponadto zwracają uwagę na to, że zły stan zdrowia (choroba) jednostek, grup i społeczności może generować problemy społeczne, np. pozostawanie bez pracy, marginalizację, naznaczenie społeczne. Pedagogika społeczna spełniająca rolę metateorii pedagogiki zdrowia, wzbogaca i poszerza swoje obszary zainteresowań poznawczo-badawczych o nowe konteksty widzenia / analizowania problemów społeczno-środowiskowych. Natomiast środowiskowa edukacja zdrowotna jest koncepcją praktycznego działania (funkcja prakseologiczna pedagogiki społecznej) w środowisku życia człowieka. Społeczno-ekologiczny model zdrowia oraz koncepcja środowiska w pedagogice społecznej stanowią teoretyczną podstawę pedagogiki zdrowia.

„Pedagogika zdrowia jest subdyscypliną pedagogiki. Jej przedmiotem zainteresowań badawczych i analiz są społeczno-środowiskowe uwarunkowania zdrowia i choroby, wieloaspektowe i wielosektorowe działania środowiskowe (instytucjonalne i pozainstytucjonalne) na rzecz zdrowia różnych grup społecznych oraz badanie i ewaluacja procesu edukacji zdrowotnej (wychowania i kształcenia) ukierunkowanej na doskonalenie zdrowia fizycznego, psychicznego i społecznego oraz umiejętności życiowych sprzyjających zdrowemu stylowi życia i poprawie jakości życia w każdym okresie życia człowieka w celu projektowania pedagogicznych (w tym edukacyjnych) działań kompensacyjnych na rzecz jednostki i środowiska, wykorzystywanych także w pracy socjalnej" (Syrek 2008, s. 21). Akcentując w badaniach pedagogiki zdrowia społeczno-środowiskowe uwarunkowania zdrowia i choroby, wskazać można na najważniejsze komponenty społecznych i środowiskowych uwarunkowań: kulturowe (normy, wartości i np. wzory zachowań zdrowotnych, świadomość zdrowotna), społeczno-ekonomiczne (zatrudnienie, bezrobocie), stres społeczny, do- 
stęp do edukacji, nierówności społeczne, politykę społeczną państwa, ubóstwo społeczne, marginalizację niektórych grup społecznych, dostęp do służby zdrowia. Zadania poznawczo-badawcze będące $\mathrm{w}$ obszarze badań polegałyby na diagnozowaniu społeczno-środowiskowych determinantów zdrowia i choroby jednostek, grup i społeczności, ich potrzeb zdrowotnych i potrzeb w zakresie edukacji zdrowotnej. Natomiast wieloaspektowe badania i analizy związane z procesem edukacji (kształcenie i wychowanie) dotyczyłyby diagnozowania potrzeb edukacyjnych $\mathrm{w}$ zakresie zdrowia, stanowiących punkt wyjścia do projektowania kompensacyjnych zmian $\mathrm{w}$ środowisku na rzecz zdrowia i doskonalenia jakości życia. W tym zakresie znaczącym działaniem jest przygotowanie odpowiednich narzędzi badawczych $\mathrm{z}$ wykorzystaniem medycznych i społecznych mierników zdrowia i choroby (por. Syrek 2008, s. 23-25). Nauki pedagogiczne, $\mathrm{w}$ tym pedagogika zdrowia, korzystają $\mathrm{z}$ metod badań stosowanych w naukach społecznych i posługują się aparatem pojęciowym właściwym dla nauk pedagogicznych / społecznych, korzystając także z pojęć zaczerpniętych z medycyny, socjologii, psychologii i innych nauk, ponieważ ich charakter ma wymiar interdyscyplinarno-integracyjny. Podstawowymi pojęciami dla pedagogiki zdrowia są: zdrowie (w ujęciu holistycznym), choroba (ujęcie socjologiczne), edukacja zdrowotna (kształcenie i wychowanie), umiejętności życiowe, diagnoza społeczna, kompensacja, wsparcie społeczne, profilaktyka społeczna, promocja zdrowia itd.

Prekursorka klasycznej pedagogiki społecznej zwracała uwagę na znaczenie edukacji środowiskowej, aby budować „lepszą przyszłość”. Edukacja środowiskowa (community education) występuje $\mathrm{w}$ wielu formach, polega nie tylko na przekazywaniu niezbędnej wiedzy, zgodnie z potrzebami środowiska, ale także na działaniach w środowisku (community work) oraz tzw. wzmacnianiu społecznym (empowering). Wyłaniają się zatem zadania dla pedagoga społecznego (community educator), pracownika socjalnego (community worker) i edukatora zdrowia (zob. Przecławska 1996, s. 27). Edukacja zdrowotna jest podstawowym pojęciem i jednym $\mathrm{z}$ podstawowych narzędzi promocji zdrowia. Jej celem jest podnoszenie świadomości i umiejętności zdrowotnych sprzyjających zachowaniom prozdrowotnym i zdrowemu stylowi życia. Barbara Woynarowska (2017) analizując to pojęcie podkreśla, że edukacja zdrowotna jest całożyciowym procesem uczenia się ludzi, jak żyć, aby zachować i doskonalić dobrostan zdrowia własny i innych ludzi, a w sytuacji choroby / niepełnosprawności, uczestniczyć w leczeniu, zmniejszać jej skutki i radzić sobie. Do najważniejszych jej cech należą: koncentrowanie się na uczeniu (learning), aktywność i zaangażowanie podmiotu uczącego się, prowadzenie edukacji przez całe życie, dostosowując się do potrzeb i zachodzących zmian, 
oddziaływanie na jednostki, grupy i społeczności zdrowe i chore w celu zwiększenia ich kompetencji w zakresie dbałości o zdrowie, dobrowolność udziału, planowanie edukacji zdrowotnej opartej na naukowych teoriach, wykorzystanie różnych metod i form $\mathrm{w}$ tym procesie. Należy zwrócić uwagę, iż edukacja zdrowotna powinna być dostosowania do wieku, konkretnego środowiska i potrzeb edukacyjnych danej społeczności. Edukację zdrowotną można ujmować jako kluczowy komponent promocji zdrowia, jej miejsca w profilaktyce chorób i zachowań ryzykownych oraz w terapii chorób (Woynarowska 2017, s. 96-97, 106). Spojrzenie na edukację zdrowotną z perspektywy pedagogiki zdrowia akcentuje jej kilka kontekstów, tj. może ona być analizowana, badana, organizowana (działanie) w różnych aspektach: ze względu na zakres społeczno-środowiskowy (różne poziomy organizacji społecznej, np. środowisko globalne, lokalne, rodzinne, szkolne); ze względu na kategorie wieku (proces całożyciowy, np. dzieci, młodzież, seniorzy); ze względu na stan zdrowia (osoby przewlekle chore, niepełnosprawne); jako kompensacja (dotyczy wyrównywania braków w zakresie wiedzy o zdrowiu), zagrożeń zdrowia, umiejętności życiowych; jako przedmiot nauczania na wszystkich szczeblach kształcenia zgodnie z przyjętymi standardami nauczania; jako element pracy socjalnej zgodnie z potrzebami; jako obszar wsparcia społecznego (Syrek 2008, s. 28-29). Może dotyczyć różnych obszarów (np. edukacja żywieniowa, seksualna, zdrowia psychicznego itd.). Należy zwrócić uwagę, iż nie można edukacji zdrowotnej sprowadzać tylko do przekazywania wiedzy o zdrowiu / chorobie. Polega ona przede wszystkim na tworzeniu warunków sprzyjających wprowadzaniu zmian związanych z podejmowaniem wysiłków na rzecz wzrostu / wzmacniania kompetencji jednostek i społeczności w zakresie samodzielnego działania na rzecz zdrowia na różnych poziomach organizacji społecznej. Niezbędna zatem staje współpraca międzysektorowa (polityka społeczna, instytucje, organizacje społeczne, zbiorowości społeczne - Słońska 2001, s. 70-71). Znaczącym elementem włączania się w działania wielosektorowe jest podejmowanie badań naukowych $\mathrm{w}$ obszarach zdrowia i choroby, a także monitorowanie problemów zdrowotnych społeczeństwa, w tym dzieci i młodzieży (zob. np. Szymańczak 2014; Mazur 2014; Cywińska 2014; Jankowiak, Błaszczyk 2017; Piorunek 2018). W literaturze przedmiotu znajdujemy wiele definicji promocji zdrowia - według Światowej Organizacji Zdrowia jest to proces, który umożliwia ludziom zwiększenie kontroli nad własnym zdrowiem, czynnikami je warunkującym i jego poprawę. Wraz z rozwojem promocji zdrowia powstają nowe definicje, bardziej rozwinięte, podkreślające przykładowo, że promocja zdrowia polega na zrównoważonym rozwijaniu zdrowia pozytywnego, profilaktyki chorób poprzez politykę zdrowotną, rozwój strate- 
gii i działań obejmujących wzajemnie powiązane obszary (społeczne, ekonomiczne, kulturowe, fizyczne, edukacyjne zainicjowane przez społeczność i z jej udziałem). To także zaplanowane mechanizmy edukacyjne i polityczne, środowiskowe, prawne i organizacyjne, które sprzyjają tworzeniu warunków życia sprzyjających zdrowiu jednostek grup społecznych i społeczności (Woynarowska 2017, s. 121). Spośród wielu podejść do strategii promocji zdrowa warto wskazać podejście siedliskowe jako szczególnie przydatne w pedagogice zdrowia. Siedlisko dla zdrowia stanowi zmieniający się system społeczny doskonalący zdrowie. Chodzi o interwencję w systemy społeczne, w których ludzie żyją ludzie, i w których wzajemnie powiązane czynniki środowiskowe, organizacyjne i osobiste mają znaczenie dla zdrowia i samopoczucia (Woynarowska 2017, s. 123). Podejście siedliskowe do promocji zdrowia opiera się na partycypacji i wspólnocie społecznej akcentowanej także przez pedagogów społecznych (zob. np. Pilch 2018). Spośród wielu strategii promocji zdrowia do współczesnych należy model ukierunkowany na upodmiotowienie jednostek i społeczności (empowerment model), w którym akcentuje się znaczenie aktywności, dobrowolności, swobodę wyborów jednostkowych / indywidualnych i wyborów na poziomie społeczności. Model ten wskazuje na wieloaspektowość i złożoność komponentów promocji zdrowia, a jego podstawą jest edukacja i prozdrowotna polityka społeczna. Upodmiotowienie jednostek i społeczności stanowi najważniejszy element tego modelu, ponieważ dotyczy kontroli nad własnym zdrowiem i życiem, a upodmiotowienie społeczności dotyczy działania wspólnego (w pedagogice społecznej to siły społeczne środowiska), aby wpływać na czynniki mające znaczenie dla zdrowia i je kontrolować. Edukacja zdrowotna w tym modelu spełnia dwie funkcje: tworzy warunki, w których ludzie uczą się o zdrowiu, jego zasobach, zagrożeniach i chorobach oraz oddziałuje na decydentów, tworzących politykę społeczną, decydujących o funkcjonowaniu środowisk oraz wspierających działania na rzecz zdrowia jednostek i społeczności (Woynarowska 2017, s. 124-127). Znaczenie edukacji zdrowotnej w strategii / modelu promocji zdrowia koresponduje z ujęciem definicyjnym edukacji zaproponowanym przez Zbigniewa Kwiecińskiego (1991, s. 89), według którego jest to „ogół wpływów na jednostki i grupy ludzi, sprzyjających takiemu ich rozwojowi, aby w najwyższym stopniu stały się one świadomymi i twórczymi członkami wspólnoty społecznej, kulturowej i narodowej oraz były zdolne do aktywnej samorealizacji, własnej tożsamości i własnego JA poprzez podejmowanie zadań ponadosobowych [...] to prowadzenie drugiego człowieka ku wyższym poziomom rozwojowym, jego własna aktywność w osiąganiu pełnych i swoistych dlań możliwości, to ogół czynności i procesów sprzyjających rozwojowi oraz stan ich efektów, czyli osią- 
gnięty poziom kompetencji, tożsamości, podmiotowości”. Definicja ta, z perspektywy pedagogiki zdrowia, wydaje się być wyjątkowo interesująca, ponieważ akcentuje te wszystkie komponenty jednostkowe / indywidualne i społeczne, dla których zdrowie jednostek i grup, społeczności jest $\mathrm{z}$ jednej strony istotną podstawą, a z drugiej także celem podjętych działań. Szczególnym akcentem podsumowującym rozważania podjęte $\mathrm{w}$ artykule, a dotyczącym zdrowia jednostek i społeczności jako kapitału społecznego, ale i odpowiedzialności państwa za zdrowie społeczeństwa, jest Ustawa o zdrowiu publicznym z dnia 11 września 2015 (Dz. U. 2015.poz.1916), gdzie w art. 2 określone zostały najważniejsze zadania zdrowia publicznego, które dotyczą: monitorowania i oceny zdrowia społeczeństwa, zagrożeń zdrowia i jakości życia związanej ze zdrowiem społeczeństwa; edukacji zdrowotnej i dostosowania jej do potrzeb różnych grup społecznych, a w szczególności dzieci i młodzieży; promocji zdrowia; profilaktyki chorób; działań związanych z rozpoznawaniem, eliminowaniem i ograniczaniem zagrożeń dla zdrowia fizycznego i psychicznego w środowisku zamieszkania, nauki, pracy i rekreacji; monitorowanie efektywności świadczonej opieki zdrowotnej w odniesieniu do potrzeb; inspirowanie i prowadzenie badań naukowych dotyczących zdrowia publicznego i współpraca międzynarodowa $\mathrm{w}$ tym zakresie; prowadzenie działań ograniczających nierówności w zdrowiu wynikających $\mathrm{z}$ uwarunkowań społeczno-ekonomicznych; podejmowanie działań w sferze aktywności fizycznej społeczeństwa. Realizacja tych zadań spoczywa na różnych instytucjach i podmiotach społecznych. Mając jednak na uwadze współczesne zagrożenia dobrostanu zdrowotnego jednostek i społeczności konieczna staje się ewaluacja realizacji zadań wyznaczonych przepisami ustawy o zdrowiu publicznym.

\section{Bibliografia}

Chrabąszcz R., Frączek M., i współ. (2015), Ludzie młodzi a nierówności społeczne. Kraków na tle Europy, Wydawnictwo Uniwersytetu Ekonomicznego, Kraków.

Cianciara D., (2015), Przyczyny i przyczyny przyczyn nierówności w zdrowiu, „Hygeia Public Health", 50(3).

Cywińska M. (red.), (2014), Problemy współczesnego dziecka. Wybrane aspekty, Wydawnictwo Naukowe UAM, Poznań.

Czapiński J., (2017), Psychologia szczesścia. Kto, kiedy, dlaczego kocha życie i co z tego wynika, czyli nowa odsłona teorii cebulowej,Wydawnictwo Naukowe Scholar, Warszawa.

Demel M., (1980), Pedagogika zdrowia, Wydawnictwa Szkolne i Pedagogiczne, Warszawa.

Demel M., (1965), Wychowanie zdrowotne jako dyscyplina pedagogiczna, „Wychowanie Fizyczne i Higiena Szkolna", 3.

Demel M., Mazurkiewicz E.A., Wentlandtowa H., (1976), Pedagogika zdrowia. (Oświata zdrowotna), [w:] Stan i perspektywy rozwoju nauk pedagogicznych, W. Okoń (red.), PWN, Warszawa. 
Domaradzki J., (2013), O skrytości zdrowia. O problemach z konceptualizacja pojęcia zdrowie, „Hygeia Public Health”, 48(4).

Gaweł A., (2017), Refleksje wokót tożsamości naukowej pedagogiki zdrowia, [w:] Pedagogika zdrowia, B. Zawadzka, J. Skrzypek (red.), Wydawnictwo Uniwersytetu Jana Kochanowskiego, Kielce.

Heszen I., Sęk H., (2007), Psychologia zdrowia, PWN, Warszawa.

Hosseinpoor A.R., Bergen N., Schlothenber A., Boerma T., (2018), National health inequality monitoring: current challenges and opportunities, „Journal Global Health Action”, 11 (supl.).

Jankowiak B., Matysiak-Błaszczyk A. (red.), 2017, Młodzież między ochrona a ryzykiem. Wspieranie rozwoju oraz pomoc psychologiczno-pedagogiczna dla adolescentów i adolescentem, Wydawnictwo Uniwersytetu im. A. Mickiewicza, Poznań.

Korzeniowska E., Puchalski K., (2015), Nierówności edukacyjne a zachowania zdrowotne i zdrowie, [w:] Socjologia medycyny w Polsce z perspektywy pótwiecza, A. Ostrowska, M. Skrzypek (red.), Wydawnictwo IFiS PAN, Warszawa.

Kotarbiński T., (1961), Elementy teorii poznania, logiki formalnej i metodologii nauk, Wydawnictwo Ossolineum, Wrocław.

Krawański A., (2003), Ciało i zdrowie człowieka w nowoczesnym systemie wychowania fizycznego, Wydawnictwo Akademii Wychowania Fizycznego, Poznań.

Kwieciński Z., (1991), Edukacja jako wartość odzyskiwana wspólnie (Głos w dyskusji o uspołecznieniu oświaty), „Edukacja”, nr 1.

Marynowicz-Hetka E., (2006), Pedagogika społeczna. Podręcznik akademicki, PWN, Warszawa.

Mazur J., (2010), Społeczne nierówności w zdrowiu subiektywnym młodzieży szkolnej w Polsce na tle Unii Europejskiej. Wybrane aspekty metodologiczne ilustrowane wyniki międzynarodowych badań, Instytut Matki i Dziecka, Warszawa.

Mazur J. (red.), (2014), Zdrowie i zachowania zdrowotne młodzieży szkolnej w Polsce na tle wybranych uwarunkowań socjodemograficznych. Wyniki badań HBSC 2014, Instytut Matki i Dziecka, Warszawa.

Mazurkiewicz E.A., (1983), Sprawność działania socjalnego w pedagogice społecznej Heleny Radlińskiej, Zakład Narodowy im. Ossolińskich, Wrocław.

Mielec B., (2009), Duchowy wymiar zdrowia człowieka. Próba nakreślenia niektórych możliwości interpretacyjnych, [w:] Promocja zdrowia $w$ teorii i praktyce psychologicznej, H. Wrona-Polańska, J. Mastalski (red.), Wydawnictwo Uniwersytetu Jagiellońskiego, Kraków.

Modrzewski J. (red.), (2018), Środowisko uczestnictwa społecznego jednostek, kategorii i grup (doświadczenia socjalizacyjne i biograficzne), Wydawnictwo Naukowe UAM, Poznań.

Ostrowska A., (2010), Zróżnicowania społeczne i nierówności w zdrowiu, [w:] Socjologia $z$ medycyną. W kręgu myśli naukowej Magdaleny Sokołowskiej, W. Piątkowski (red.), Wydawnictwo IFiS PAN, Warszawa.

Parsons T., (1993), Struktura społeczna a osobowość, Wydawnictwo PWE, Warszawa.

Pilch T., (2018), Jednostka - środowisko - wspólnota. Jednostka i środowisko jej życiowej aktywności. Między indywidualizacja a współczesnymi formami egzystencji, [w:] Środowiska uczestnictwa społecznego jednostek, kategorii i grup (doświadczenia socjalizacyjne i biograficzne), J. Modrzewski, A. Matysiak-Błaszczyk, E. Włodarczyk (red.), Wydawnictwo Naukowe UAM, Poznań.

Piorunek M. (red.), (2018), Spoleczne i jednostkowe konteksty pomocy, wsparcia społecznego i poradnictwa, Wydawnictwo Naukowe UAM, Poznań. 
Przecławska A. (red.), (1996), Pedagogika społeczna kręgi poszukiwań, Wydawnictwo Akademickie „Żak”, Warszawa.

Radlińska H., (1961), Pedagogika społeczna, Zakład Narodowy im. Ossolińskich, Wrocław.

Słońska Z., (2001), Współczesna wizja edukacji zdrowotnej a promocja zdrowia, [w:] Teoretyczne podstawy edukacji zdrowotnej. Stan i oczekiwania, B. Woynarowska, M. Kapica (red.), Wydawnictwo KOWEZ, Warszawa.

Syrek E., (2008), Zdrowie i wychowanie a jakość życia. Perspektywy i humanistyczne orientacje poznawcze, Wydawnictwo Uniwersytetu Śląskiego, Katowice.

Syrek E., (2017), Subdyscypliny pedagogiki, socjologii i psychologii. Konteksty interdyscyplinarnego zainteresowania zdrowiem i choroba $w$ naukach społecznych, [w:] Pedagogika zdrowia w teorii i praktyce, B. Zawadzka, T. Łączek (red.), Wydawnictwo Uniwersytetu Jana Kochanowskiego, Kielce.

Sztompka P., (2016), Kapitał społeczny. Teoria przestrzeni międzyludzkiej, Wydawnictwo Znak, Kraków.

Szymańczak J. (red.), (2014), Zdrowie dzieci i młodzieży. Wybrane zagadnienia, Studia Biura Analiz Sejmowych Kancelarii Sejmu, 2(38), Warszawa.

Śliwerski B., (2015), Nauki o wychowaniu a pedagogika, „Nauki o Wychowaniu. Studia Interdyscyplinarne", 1.

Tobiasz-Adamczyk B., (2000), Wybrane elementy zdrowia i choroby, wyd. 3, Wydawnictwo Uniwersytetu Jagiellońskiego, Kraków.

Winiarski M., (2017), W kręgu pedagogiki społecznej. Studia-szkice-refleksje, „Studia i Monografie", nr 78, Wydawnictwo Społecznej Akademii Nauk, Łódź-Warszawa.

Wojtyniak B., Marek M., Goryński P., (2015), Charakterystyka Projektu Predefiniowanego dotyczącego ograniczania społecznych nierówności w zdrowiu, Program PL 13, Norweski Mechanizm Finansowy, „Zdrowie Publiczne i Zarządzanie. Zeszyty Naukowe Ochrony Zdrowia”, 13(1).

Woynarowska B., (2007), Edukacja zdrowotna. Podręcznik akademicki, Państwowe Wydawnictwo Naukowe, Warszawa.

Woynarowska B. (red.), (2017), Edukacja zdrowotna. Podstawy teoretyczne. Metodyka. Praktyka, Państwowe Wydawnictwo Naukowe, Warszawa.

Zawadzka B., (2017), Pedagogika zdrowia (ujęcie historyczne), [w:] Pedagogika zdrowia w teorii i praktyce, B. Zawadzka, T. Łączek (red.), Wydawnictwo Uniwersytetu Jana Kochanowskiego, Kielce.

Zdrowie 21. Zdrowie dla wszystkich w XXI wieku, (2001), tłum. J.B. Karski, Centrum Systemów Informacyjnych Ochrony Zdrowia we współpracy z Uniwersyteckim Wydawnictwem Medycznym Vesalius, Warszawa-Kraków.

Zdrowie 2020: Europejska polityka wspierająca działania rządów i społeczeństw na rzecz zdrowia $i$ dobrostanu człowieka, World Health Organization, Regional Office for Europe, Malta, 10-13 września 2012. 